Ilmu Pertanian (Agricultural Science)

Vol. 3 No. 2 August, $2018: 103-109$

Available online at http://journal.ugm.ac.id/jip

DOI: doi.org/10.22146/ipas.32699

\title{
Genetic Variation in Selected Individuals Based on Number of Capsules in M5 Sesame Mutant Lines Detected by RAPD
}

\author{
Masruru Kholida ${ }^{1}$, Taryono ${ }^{1,2 *}$ and Rani Agustina Wulandari ${ }^{1}$ \\ ${ }^{1}$ Faculty of Agriculture, Gadjah Mada University, Bulaksumur, Yogyakarta 55281 \\ Jln. Flora no. 1, Bulaksumur, Sleman, Yogyakarta 5528, Indonesia \\ ${ }^{2}$ Agrotechnology Innovation Centre, Gadjah Mada University, Yogyakarta, Indonesia \\ Jl. Tanjung Tirto, Kali Tirto, Berbah, Kabupaten Sleman, Yogyakarta \\ *Corresponding email: tariono60@gmail.com
}

\begin{abstract}
Sesame (Sesamum indicum L.) is major oilseed crops with advantages in health and food industry. Due to self pollinated crop, breeding program in sesame utilized gamma rays irradiation to increase genetic variation. The research material consisted of 164 genotypes from 22 selected individual mutant line based on the number of capsules in M5 generation. This study is to detect genetic variation in selected individuals based on number of capsules in M5 generation of sesame mutant line using RAPD markers. The analysis consists of percentage of polymorphic loci, analysis of molecular variance and visualized in cluster and co-ordinate analysis. Fifteen primers RAPD were able to amplified 237 loci. Each genotype in populations had the similarity coefficient of $0.29-0.85$. Variance within selected individual line (66\%) was higher than variance among selected mutant lines (34\%). Variance in each selected individual line contributed to its high value. Line 34 showed the lowest polymorphism (23.21\%) and line 19 depicted the highest polymorphism $(61.60 \%)$.
\end{abstract}

Keywords: Molecular marker, mutation, polymorphism.

\section{INTRODUCTION}

Sesame is cultivated for its oil content. The unsaturated fatty acids composed about $80 \%$ of sesame oil and its beneficial for health. The lignin contained in sesame oil caused the resistance to oxidation and gave long shelf life. Sesame and other plants belong to the genus Sesamum and the Pedaliaceae family demonstrated very wide range of adaptability to environmental conditions. Sesame thrives in soil with low fertility and limited water availability (Bedigian, 2010; Weiss, 1971). In Indonesia, sesame is mostly used in food industry as the whole seed in bakery or as cooking oil.

Genetic variation in self-pollinated crops such as sesame is low. Mutation is one of methods to generate genetic variation (Acquaah, 2012). Mutations occured randomly throughout the genome and within the locus or genes, thereby not only producing desired mutation but allowing the emergence of other mutations that can increase the diversity of a germplasm. Induced mutations with gamma ray irradiation are often performed due to their wide availability and flexibility of use (Foster \& Shu, 2012).

Homogeneous seeds of black and white sesame seeds were treated with 100 - 800 Gy 60Co gamma rays. M2 generation populations are screened with $6 \mathrm{gl}^{-1} \mathrm{NaCl}$ solution for salinity tolerance and the results were planted to produce M3 generation (Pramujari, 2015, personal comm.). Further selection which based on plant height and number of capsules per plant in M4 resulted in significant decreased of genetic variability of seed yield and yield components in M5 generations of sesame mutant lines (Aristya, 2017).

Genetic variance detection with molecular markers offered several advantages over morphology, as they were not confounded by environmental and able to detect polymorphism in DNA level (Zainudin et al., 2014). Random Amplified Polymorphic DNA (RAPD) is one of methods in molecular markers based on amplification with Polymerase Chain 
Reaction (PCR). Several study in genetic variation using RAPD in sesame are conducted by Bhat et al. (1999) and Ercan et al. (2004), while Taryono et al. (2011) using RAPD to detect mutational changes in sorghum. This study is to detect genetic variation in selected individuals based on number of capsules in M5 generation of sesame mutant lines.

\section{MATERIALS AND METHODS}

The entire research work was carried out at Genetics and Plant Breeding Laboratory, Faculty of Agriculture, Universitas Gadjah Mada during the year 20162017.

\section{Plant Material}

Twenty two selected individuals based on number of capsules from M5 generation were used in this research. Each of selected individuals were grown in separated rows. The samples were randomly collected from each line and the total were 164 individual samples (Table 1).

\section{DNA Isolation}

DNA was extracted from $0.1 \mathrm{mg}$ well-developed leaves using CTAB method (Doyle \& Doyle, 1990). The total DNA were extracted with CTAB buffer and then diluted it to obtain final concentration of $2.5 \mathrm{ng} \mu \mathrm{L}^{-1}$

\section{RAPD Analysis}

This research used 15 primers for RAPD analysis based on polymorphic bands. PCR touchdown was carried out to optimize the amplification. The initial heating was performed at $95^{\circ} \mathrm{C}$ for 5 minutes and then followed by 15 cycles of denaturation at $95^{\circ} \mathrm{C}$ for $15 \mathrm{sec}$; annealing at $41^{\circ} \mathrm{C}$ for $30 \mathrm{sec}$; and elongation at $72^{\circ} \mathrm{C}$ for $90 \mathrm{sec}$ then repeated for the annealing temperatures at $39^{\circ} \mathrm{C}$ and $37^{\circ} \mathrm{C}$ and followed by final elongation at $72^{\circ} \mathrm{C}$ for 7 minutes. Amplification was carried out in thermal cycler BioRad T100TM. The amplification results were analyzed by electrophoresis on $1.5 \%$ agarose gels 1st BASE stained with Floro Safe 1st BASE and photographed under ultraviolet light. Molecular weights were estimated using a 100 bp DNA ladder.

\section{Data Analysis}

Each band visualized in gel electrophoresis scored for 1 for the presence and 0 for the absent of

Table 1. Population of samples for RAPD analysis

\begin{tabular}{|c|c|c|c|}
\hline Treatment & $\begin{array}{c}\text { Selected } \\
\text { Individual mutant }\end{array}$ & $\begin{array}{l}\text { Sample } \\
\text { number }\end{array}$ & Population Size \\
\hline Control & 39 & 12 & 12 \\
\hline \multirow[t]{5}{*}{$100 \mathrm{~Gy}$} & 17 & 11 & 45 \\
\hline & 18 & 6 & \\
\hline & 19 & 13 & \\
\hline & 20 & 9 & \\
\hline & 21 & 6 & \\
\hline \multirow[t]{3}{*}{$300 \mathrm{~Gy}$} & 23 & 7 & 16 \\
\hline & 24 & 5 & \\
\hline & 25 & 4 & \\
\hline \multirow[t]{2}{*}{$400 \mathrm{~Gy}$} & 26 & 9 & 19 \\
\hline & 27 & 10 & \\
\hline \multirow[t]{4}{*}{$500 \mathrm{~Gy}$} & 28 & 10 & 30 \\
\hline & 29 & 11 & \\
\hline & 30 & 4 & \\
\hline & 31 & 5 & \\
\hline $600 \mathrm{~Gy}$ & 32 & 5 & 5 \\
\hline \multirow[t]{3}{*}{$700 \mathrm{~Gy}$} & 33 & 7 & 20 \\
\hline & 34 & 4 & \\
\hline & 35 & 9 & \\
\hline \multirow[t]{4}{*}{$800 \mathrm{~Gy}$} & 36 & 7 & 17 \\
\hline & 37 & 7 & \\
\hline & 38 & 3 & \\
\hline & & & $\Sigma=164$ \\
\hline
\end{tabular}


Table 2. Amplification Result with 15 Primers RAPD

\begin{tabular}{lcccc}
\hline Primer & Sequence (5'-3') & $\begin{array}{c}\text { Number of loci } \\
\text { Amplified }\end{array}$ & Band Size (bp) & \% Polymorphism \\
\hline OPA 7 & GAAACGGGTG & 19 & $250-2500$ & 100 \\
OPA 10 & GTGATCGCAG & 16 & $200-1700$ & 100 \\
OPB 7 & GGTGACGCAG & 17 & $350-2500$ & 100 \\
OPB 8 & GTCCACACGG & 11 & $300-1700$ & 100 \\
OPB 11 & GTAGACCCGT & 9 & $300-1500$ & 100 \\
OPB 12 & CCTTGACGCA & 14 & $200-2000$ & 100 \\
OPB 18 & CCACAGCAGT & 15 & $200-1700$ & 100 \\
OPC 4 & CCGCATCTAC & 17 & $250-2000$ & 100 \\
OPC 5 & GATGACCGCC & 17 & $250-2000$ & 100 \\
OPC 8 & TGGACCGGTG & 17 & $300-2000$ & 100 \\
OPC 11 & AAAGCTGCGG & 17 & $200-3000$ & 100 \\
OPC 12 & TGTCATCCCC & 19 & $250-2000$ & 100 \\
OPC 16 & CACACTCCAG & 16 & $270-2500$ & 100 \\
OPD 12 & CACCGTATCC & 15 & $300-2500$ & 100 \\
OPD 20 & ACCCGGTCAC & 18 & $250-2000$ & 100 \\
\hline & & $\Sigma=237$ & & \\
\hline
\end{tabular}

Table 3. Percentage of Polymorphic Loci in Selected Individual with 15 Primers RAPD

\begin{tabular}{|c|c|}
\hline $\begin{array}{l}\text { Selected Individual mu- } \\
\text { tant (line) }\end{array}$ & $\begin{array}{c}\text { Percentage of } \\
\text { Polymorphic Loci }(\%)\end{array}$ \\
\hline 39 (control) & 50.21 \\
\hline 17 & 50.21 \\
\hline 18 & 46.41 \\
\hline 19 & 61.60 \\
\hline 20 & 54.85 \\
\hline 21 & 45.99 \\
\hline 23 & 52.32 \\
\hline 24 & 46.41 \\
\hline 25 & 33.76 \\
\hline 26 & 45.57 \\
\hline 27 & 45.99 \\
\hline 28 & 47.68 \\
\hline 29 & 49.37 \\
\hline 30 & 36.71 \\
\hline 31 & 49.37 \\
\hline 32 & 40.51 \\
\hline 33 & 50.21 \\
\hline 34 & 23.21 \\
\hline 35 & 52.74 \\
\hline 36 & 54.43 \\
\hline 37 & 37.97 \\
\hline 38 & 25.32 \\
\hline
\end{tabular}


bands. Analysis of percentage of polymorphic loci, Analysis of Molecular Variance (AMOVA) and Principal Coordinate Analysis (PCoA) was carried out with GenAlEx 6.1. Coefficient genetic similarity and cluster analysis which based on Unweighted Pair Group Method with Arithmatic (UPGMA) was carried out with NTSYSpc v 2.02.

\section{RESULTS AND DISCUSSION}

Amplification results based on 15 primer RAPD showed $100 \%$ polymorphism and were able to amplify 237 loci (Table 2). The average number of loci being amplified was 15.8 for each primer. In primer OPB 8 (Abdellatef et al., 2008) and OPC 4 (Salazar et al., 2006) also produced $100 \%$ polymorphism and were able to amplify 6 and 7 loci. The number of loci that was formed depent on how the primer recognizes the homologous DNA template. The more homologous DNA sites with primers, the more number of loci are amplified (Poerba \& Yuzammi, 2008). Figure 3 showed polymorphic bands as shown by the arrows among samples from selected individual 28 using primer OPA 10.

The percentage of polymorphic loci is used to determine the variability in the group (Laurentin, 2009). In this study, the percentage of polymorphic loci at the highest selected numbers was in line 19 with $61.60 \%$, while the lowest was in line 34 with $23.21 \%$ (Table 3). Genetic variation in line 19 was considered as the biggest contributor for the variation

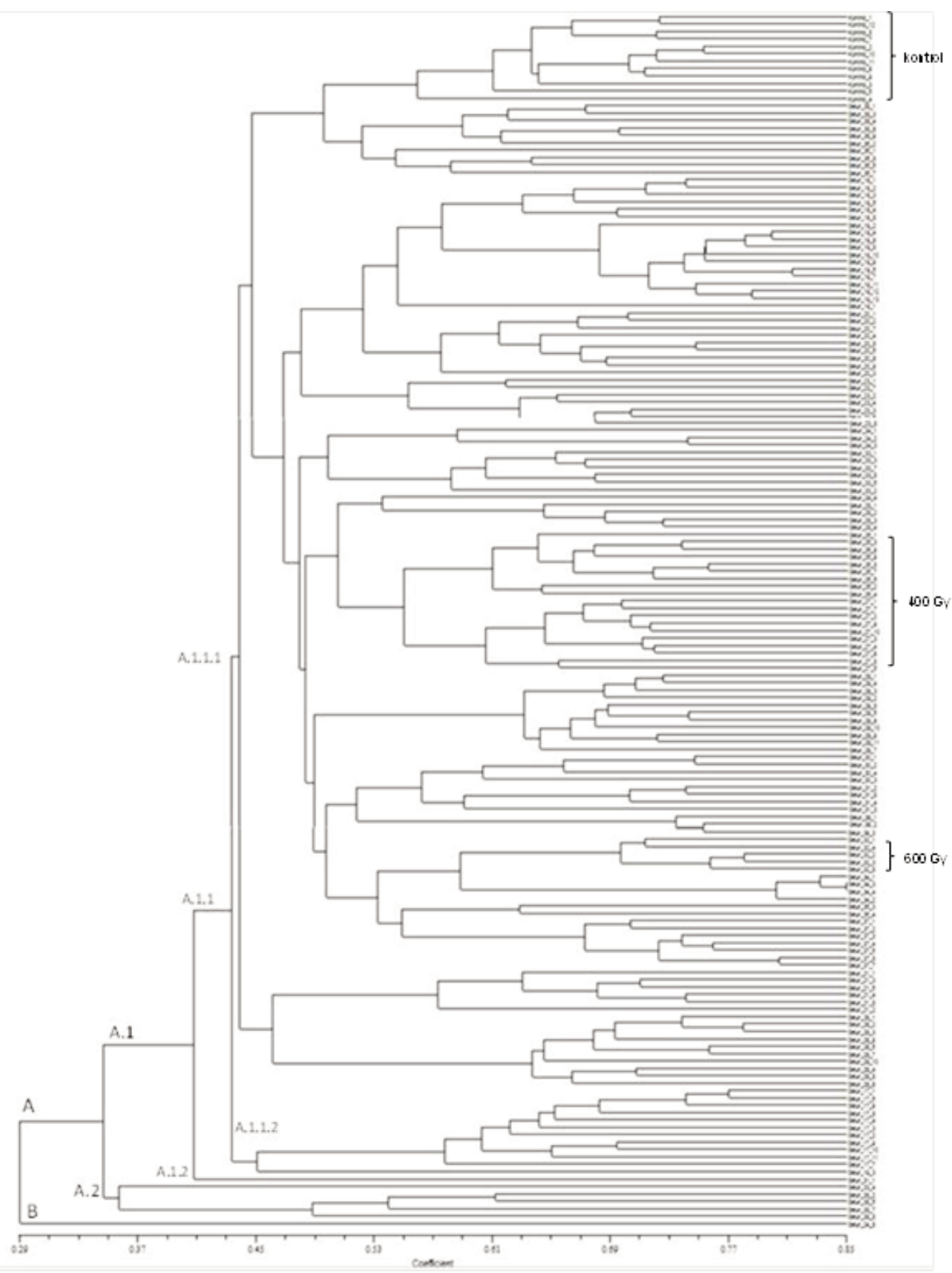

Figure 1. Dendrogram of 164 selected individual lines 
Table 4. AMOVA for Selected Individual

\begin{tabular}{lccccc}
\hline Source of Variance & $\mathrm{df}$ & $\mathrm{SS}$ & $\mathrm{MS}$ & Est. Var. & (\%) \\
\hline Between Selected Individual & 21 & 2365.338 & 112.635 & 12.105 & 34 \\
Within Selected individual & 142 & 3268.009 & 23.014 & 23.014 & 66 \\
\hline Total & 163 & 5633.347 & & 35.119 & 100 \\
\hline
\end{tabular}

in 100 Gy dose treatment. Genetic variation within selected individual lines was higher than genetic variation among selected mutant lines (Table 4).

The similarity coefficient ranged between 0.29 0.85 (Figure 1). Two genotypes from line 34 showed the highest similarity coefficient with 0.85 . The cluster analysis divided 164 genotypes into two major groups $\mathrm{A}$ and B at similarity level 0.29 . Group B consisted of one genotypes from line 24 and group A consists of 163 genotypes from all selected individuals. Group A was divided into three subgroups at similarity level $0.35 ; 0.41$; and 0.43 . Among subgroup at similarity level 0.43 , there were four selected individual lines clustered with different similarity level (line 39, 32, 27, and 26). This cluster analysis was also supported with PCoA (Figure 2) that several selected individual lines grouped into the same quadrant. Line 32 grouped into quadrant III and line 39 grouped into quadrant I.
Mutation is the ultimate source of variation and may be caused by alteration in DNA replication or damage by radiation (de Vicente et al., 2004). Variation in DNA can be used as a source of polymorphism. In this study, 15 primers of RAPD were able to detect polymorphism in DNA level. Based on percentage of polymorphic loci, line 34 showed the lowest polymorphism and the highest polymorphism detected in line 19 with $61.60 \%$. This result was also supported by the estimated variance in Analysis of Molecular Variance (AMOVA) that genetic variation within selected individual line higher (66\%) than among selected mutant lines (34\%).

Gamma rays are a class of ionizing radiation which produce free radicals in cells that are capable of modify cells components and consequently affect different morphological, anatomical, biochemical and physiological characters of plants depending on the dose of mutation (Gafaar et al., 2016). Diverse genetic

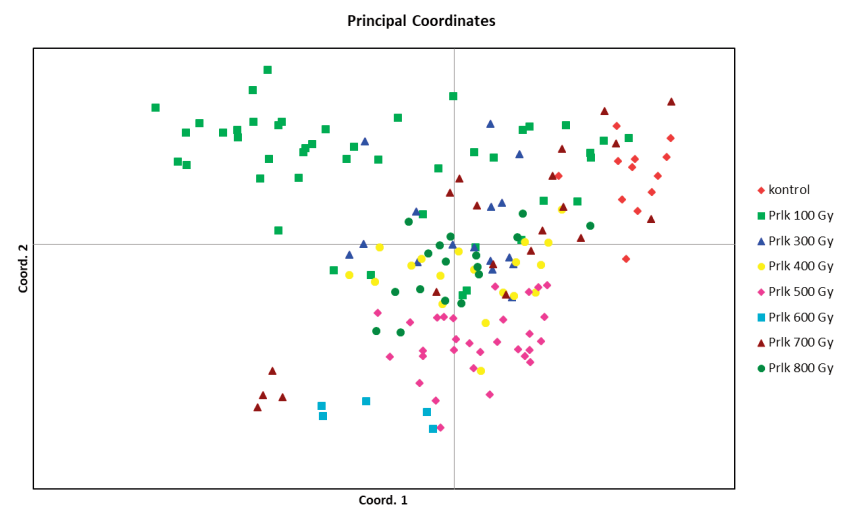

Figure 2. PCoA of 164 individual sample plants of 22 selected individual mutant lines

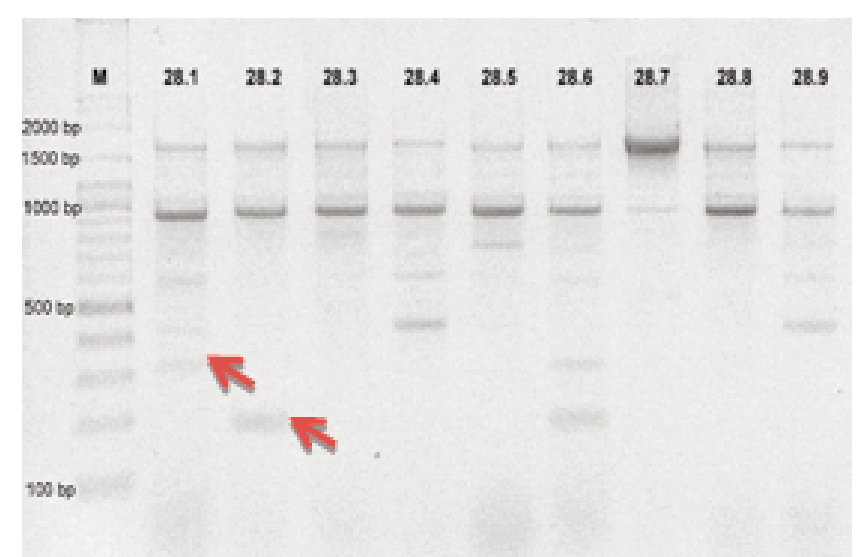

Figure 3. Amplification result from primer OPA 10 in selected individual 28 
variation as a result from different dose of gamma irradiation was recorded in wheat (Indriatama et al., 2016) and lentil (Laskar \& Khan, 2017).

Sesame is a self pollinated plants and often have lower genetic variability than outcrossing plants, and that variability tends to be found between populations (Charlesworth, 2003). In this research, AMOVA is proposed to identify molecular variation within and between population (selected individual lines). In this study, genetic variation within selected individual lines higher than among selected individual lines. In self pollinated plants, subsequent generations tend to have increased homozygous level. If the pair of genes is more than one, the decreased in heterozygous level will not be as fast as if there only one pair of genes (Mangoendidjojo, 2003). In this study, selection is based on the number of capsule from M4 generation. The number of capsule is quantitative traits that are controlled by many genes (polygenic) and each of it has little effect on expression of a plant character (Kasno \& Trustinah, 1998).

\section{CONCLUSIONS}

The distribution value of genetic variation within selected individual line (66\%) was higher than among selected individual lines (34\%). This variation resulted polymorphism which can be detected with RAPD markers. Line 34 showed the lowest polymorphism (23.21\%) whereas line 19 depicted the highest polymorphism $(61.60 \%)$. Each genotype in population had the similarity coefficient of $0.29-0.85$. This high genetic diversity within selected individual line due to different effect of dose gamma irradiation and selection based on the number of capsule as of needs further selection in subsequent generations.

\section{REFERENCES}

Abdellatef, E., R. Sirelkhatem, M.M. Mohamed Ahmed, K.H Radwan, \& M.M Khalafalla. 2008. Study of genetic diversity in Sudanese sesame (Sesamum indicum L.) germplasm using random amplified polymorphic DNA (RAPD) markers. African Journal of Biotechnology 7(24) : 4423-4427

Acquaah, G. 2012. Principles of Plant Genetics and Breeding, 2nd ed. United Kingdom: WileyBlackwell Publishing. 740 p.

Aristya, V. E., Taryono, \& R.A. Wulandari, 2017. Evaluation of Genetic Parameters in M4 and M5 Generations of Sesame Mutant Lines. SABRAO Journal, 49 (2) : 201-210

Bedigian, D. 2010. Cultivated Sesame and Wild Relatives in the Genus Sesamum L. In: Bedigian,
D. (Ed.). Sesame The genus Sesamum. Boca Ratoon: CRC Press. 33-77.

Bhat, K. V., P. P. Babrekar, \& S. Lakhanpaul 1999. Study of Genetic Diversity in Indian and Exotic Sesame (Sesamum Indicum L.) Germplasm using Random Amplified Polymorphic (RAPD) markers. Euphytica 110: 21-33

Charlesworth, D. 2003. Effects of inbreeding on the genetic diversity of populations. Phil. Trans. R. Soc. Lond. B. 358:1051-1070.

De Vicente, M. C., C. Lopez, \& T. Fulton. 2004. Genetic Diversity Analysis with Molecular Marker Data : Learning Module. International Plant Genetic Resources Institute (IPGRI), Rome, Italy.

Doyle, J.J. \& J.L. Doyle. 1990. Isolation of Plant DNA from Fresh Tissue. Focus 12 (1): 13-15

Ercan, A.G., M. Taskin, \& K.Turgut. 2004. Analysis of Genetic Diversity in Turkish Sesame (Sesamum indicum L.) Populations using RAPD Markers. Genetic resources \& Crop Evolution. 51: 599-607.

Forster, B. P. \& Q.Y. Shu. 2012. Plant mutagenesis in crop improvement: Basic terms and applications. In: Shu, Q. Y., Forster, B. P. \& Nakagawa, H. (Eds.). Plant Mutation Breeding and Biotechnology. CAB International \& FAO. 9-20.

Gaafar, R.M., M. Hamouda, \& A. Badr. 2016. Seed coat color, weight and eye pattern inheritance in gamma-rays induced cowpea M2-mutant line. Journal of Genetic Engineering and Biotechnology 14 (1) : 61-68.

Indriatama, W. M., Trikoesoemaningtyas, S. I. Aisyah, \& S. Human. 2016. Pendugaan ragam genetik dan heritabilitas karakter agronomi gandum (Triticum aestivum L.) hasil berbagai perlakuan teknik iradiasi sinar gamma. Jurnal Ilmiah Aplikasi Isotop dan Radiasi 12(2) : 7988.

Kasno, A. \& Trustinah. 1998. Pembentukan Varietas Kacang Tunggak. Monograf Balitkabi $3: 20$ 58.

Laskar, R. A. \& S. Khan, 2017. Assessment on induced genetic variability and divergence in the mutagenized lentil populations of micro sperma and macrosperma cultivars developed using physical and chemical mutagenesis. PLoS ONE 12 (9) : 1-18.

Laurentin, H. 2009. Data analysis for molecular characterization of plant genetic resources. Genet. Res. Crop Evol. 56: 277-292.

Mangoendidjojo, W. 2003. Dasar-Dasar Pemuliaan Tanaman. Kanisius. Yogyakarta. 182 p.

Poerba, Y. S. \& Yuzammi. 2008. Pendugaann keragaman genetik Amorphophallus titanium Becc. 
Berdasarkan marka Random Amplified Polymorphic DNA. Biodiversitas 9(2): 103107.

Salazar, B., Laurentin, H., Davila, M., \& Castillo, M. A. 2006. Reliability of the RAPD technique for germplasm analysis of sesame (Sesamum indicum L.) from Venezuela. Interciencia 31 (6): $456-460$.

Taryono, Cahyaningrum, P., \& Human, S. 2011. The Detection of mutational changes in Sorghum using RAPD. Indonesian Journal of Biotech. 16 (1): 66-70.
Weiss, E. A. 1971. Castor, Sesame, and Safflower. London : Leonard Hill. 311-519.

Zainudin, A., Maftuchah, \& Fitriani, H. 2014. Analysis of genetic diversity on mutants Jatropha curcas using RAPD. Energy Procedia 47: 1-6 